\title{
The incidence and causes of hypercalcaemia
}

\author{
David M. Dent, ${ }^{1}$ Jeffrey L. Miller, ${ }^{2 *}$ Leslie Klaff ${ }^{2} \uparrow$ and Jeffrey Barron ${ }^{3} \ddagger$ \\ Departments of ${ }^{1}$ Surgery, ${ }^{2}$ Medicine and ${ }^{3}$ Chemical Pathology, University of Cape Town and Groote Schuur \\ Hospital, Cape Town, South Africa
}

\begin{abstract}
Summary: A prospective screen for hypercalcaemia in 58,053 hospital in-patients was conducted over 12 months. The incidence of hypercalcaemia was $0.6 \%$, being transient in $19.2 \%$ of patients and sustained in the remainder. The most common causes in the sustained group were malignancy (45\%) and primary hyperparathyroidism (16.5\%). The incidence of primary hyperparathyroidism was $78 / 100,000$ hospital in-patients, and its discovery was directly attributable to the survey in over half the cases.
\end{abstract}

\section{Introduction}

There has been a continuing interest in the incidence of hypercalcaemia and its underlying causes. This stems both from the frequency and ease with which calcium estimations are made on routine blood analysis and the implication that hypercalcaemia may act as a marker of underlying disease. Of many causes of symptomatic and asymptomatic hypercalcaemia, primary hyperparathyroidism is a good example of a disease where repeated attempts have been made to estimate incidence and frequency. These estimates have, however, varied widely. We undertook therefore to determine, by a prospective screen, our own incidence of hypercalcaemia and the frequency distribution of its causes with particular reference to hyperparathyroidism.

\section{Methods}

A prospective screen of all hypercalcaemic hospital inpatients was undertaken over 12 non-consecutive months spanning 1983 and 1984. Groote Schuur Hospital is a general secondary and tertiary referral institution with just over 1600 beds, a major commitment to malignant disease and an active endocrine

\footnotetext{
*Present address: Division of Endocrinology and Metabolism, Hahnemann University School of Medicine, 230 North Broad Street, Philadelphia, Penn. 19102, USA.

$\nmid$ Present address: Pacific Medical Center, 1200-12th Avenue South, Seattle, Washington 98144, USA

¥Present address: Chemical Pathology Department, St Helier Hospital, Carshalton, Surrey, UK.

Correspondence: Professor D.M. Dent, Ch.M., F.R.C.S., F.C.S. (SA), Department of Surgery, Medical School, Observatory 7925, South Africa.

Accepted: 18 March 1987
}

unit. A daily computer-based list of all patients with serum calcium levels in excess of $2.6 \mathrm{mmol} / 1(10.4 \mathrm{mg} /$ $100 \mathrm{ml}$ ) was obtained. The total serum calcium was corrected for the serum albumin using the formula (calcium $+(40$-albumin $) \times 0.025 \mathrm{mmol} / \mathrm{l})$, and a case study opened for all in-patients. Sequential calcium values were recorded and a biochemical profile for each patient obtained. The samples were not specifically taken from fasting subjects and no attempt was made to avoid cuff occlusion as it has been shown that calcium elevation after 10 minutes is minimal and in the order of $0.1 \mathrm{mmol} / \mathrm{l}^{1}$

Cases were categorized into three groups: (i) exclusions (not investigated), (ii) transient hypercalcaemia (one elevation, several normal observations) and (iii) sustained hypercalcaemia. The incidence of hypercalcaemia was calculated using both the transient and sustained cases whereas the frequency distribution of causes was estimated separately in each group.

The diagnosis of primary hyperparathyroidism was made by the clinical setting of the case, the profile of calcium, phosphate, chloride and bicarbonate on the SMAC $12 / 60$, a 24 hour urinary calcium excretion rate and tubular resorbtion of phosphate and a discriminant analysis ${ }^{2}$ to distinguish hyperparathyroidism from other causes of hypercalcaemia.

Parathyroid hormone was assayed using a C-terminal directed radio-immunoassay (Immuno-nuclear Corporation) and nephrogenous cyclic AMP was assayed (Amersham International, United Kingdom). The clinical diagnosis was confirmed at surgery in symptomatic patients and the young.

For purposes of comparison all previous studies ${ }^{3-24}$ were ordered chronologically and the proportions of exclusions and transient hypercalcaemics were recalculated where appropriate.

(C) The Fellowship of Postgraduate Medicine, 1987 


\section{Results}

There were 350 patients with hypercalcaemia detected over the 12 month period. During this time there were 58,053 hospital admissions. We have excluded 12 hypercalcaemic patients as they had been discharged after a single investigation and could not be followed up. We therefore calculate our incidence to be $0.6 \%$ $(338 / 58,053)$ of hospital admissions.

\section{Transient hypercalcaemia}

In 65 patients $(19.2 \%)$ there was only one calcium elevation and more than two normal levels (Table I). In 29 of these patients the hypercalcaemia occurred during an acute cardiac event (cardiac surgery, myocardial infarction and cardiopulmonary resuscitation) or during the course of calcium infusion, (6) parenteral nutrition, (5) hyperosmolar diabetic coma (4) and pre-eclamptic toxaemia (2). In 19 instances we found no explanation for the phenomenon.

\section{Sustained hypercalcaemia}

The frequency distribution of causes was calculated in the 273 patients with sustained hypercalcaemia. The most common causes were malignant disease $(45 \%)$, thiazide diuretic administration (21\%) and primary hyperparathyroidism (17\%); less common causes were renal disease, rhabdomyolysis, thyrotoxicosis, sarcoidosis and lithium therapy. In 13 patients $(4 \%)$ the sustained hypercalcaemia remains obscure; in most of these the investigations were suggestive but not conclusive of hyperparathyroidism but neck exploration has not been undertaken for this reason and for concomitant frailty.

The primary sites of malignancy were grouped into organ systems (Table II). As such, the lung was the most common site $(30 \%)$ followed by urogenital $(15 \%)$, gastrointestinal (13\%), haematological (12\%), head and neck $(10 \%)$, breast $(8 \%)$ and unknown primary site $(8 \%)$. The mean level of serum calcium was $3.15 \pm 0.52 \mathrm{mmol} / 1$ (range 2.6-4.95) and was higher in patients with overt bone metastases $(3.27 \pm 0.61$ $\mathrm{mmol} / \mathrm{l})$ than those without $(3.08 \pm 0.46 \mathrm{mmol} / \mathrm{l})$, but not statistically significant. Follow up was complete in 81 patients of whom only 7 are alive, the mean survival time being 78 days (range $1-518$ days).

We made the diagnosis of primary hyperparathyroidism in 45 patients. We therefore calculated our incidence of primary hyperparathyroidism amongst hypercalcaemic patients to be $16.5 \%(45 / 338)$ and our incidence amongst hospital in-patients to be $0.078 \%$ (45/58053). In 21 patients the possible diagnosis of primary hyperparathyroidism had been made by the attending clinician and in the remaining 25 the diagnosis was directly attributable to the survey. Fifteen of the undiagnosed group were symptomatic, the manifestations of hypercalcaemia being renal stones (3), confusional state (3), pancreatitis (2), peptic ulcer (2), polymyalgia (1) and various combinations of these (4). The diagnosis of primary hyperparathyroidism was proven in each of the 27 cases where neck exploration was undertaken. In the remaining 19 patients necko exploration was not undertaken due to one or a combination of patient refusal, advanced age, severe concomitant disease or mild hypercalcaemia.

Table I Calcium levels in each category (mmol/1); individual levels given in groups with small numbers

n Mean \pm standard deviation (highest)

Transient hypercalcaemia (65)

Cardiac event

Calcium infusion

Parenteral nutrition

Hyperosmolar diabetic coma

Pre-eclamptic toxaemia

Unexplained

Sustained hypercalcaemia (273)

Malignancy

Thiazide diuretic

Primary hyperparathyroidism

Renal

Rhabdomyolysis

Thyrotoxicosis

Sarcoidosis

Lithium therapy

Obscure
$292.76 \pm 0.17(3.41)$

$6(2.63 ; 2.98 ; 2.68 ; 2.16 ; 2.67 ; 2.90)$

$5(2.7 ; 2.82 ; 2.65 ; 2.70 ; 2.70)$

$4(2.64 ; 2.68 ; 3.43 ; 2.73)$

2 (2.78; 2.69)

$192.71 \pm 0.07$ (2.92)

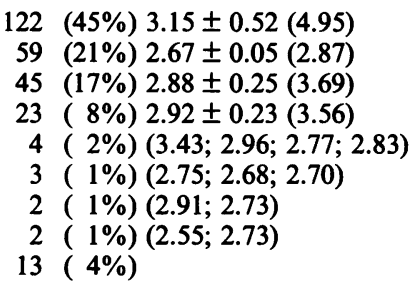


Table II Site of primary malignancy (number with overt bone metastases indicated in brackets).

\begin{tabular}{|c|c|c|c|}
\hline $\begin{array}{l}\text { Lung } \\
\text { Squamous } \\
\text { Not specified } \\
\text { Oat cell } \\
\text { Adenocarcinoma }\end{array}$ & $\begin{array}{r}37 \\
20 \\
11 \\
4 \\
2\end{array}$ & $\begin{array}{l}(8) \\
(4) \\
(1) \\
(2)\end{array}$ & $(30 \%)$ \\
\hline $\begin{array}{l}\text { Gastro-intestinal } \\
\text { Oesophagus } \\
\text { Stomach } \\
\text { Hepatocellular } \\
\text { Cholangiocarcinoma } \\
\text { Colon } \\
\text { Rectum }\end{array}$ & $\begin{array}{r}16 \\
7 \\
2 \\
3 \\
1 \\
2 \\
1\end{array}$ & (1) & $(13 \%)$ \\
\hline $\begin{array}{l}\text { Urogenital } \\
\text { Cervix } \\
\text { Kidney } \\
\text { Bladder } \\
\text { Ovary } \\
\text { Endometrium } \\
\text { Chorioncarcinoma }\end{array}$ & $\begin{array}{r}18 \\
9 \\
4 \\
1 \\
2 \\
1 \\
1\end{array}$ & $\begin{array}{l}(2) \\
(1)\end{array}$ & $(15 \%)$ \\
\hline $\begin{array}{l}\text { Haematological } \\
\text { Myeloma } \\
\text { Lymphoma } \\
\text { Leukaemia }\end{array}$ & $\begin{array}{r}15 \\
7 \\
7 \\
1\end{array}$ & $\begin{array}{l}(7) \\
(7) \\
(1)\end{array}$ & $(12 \%)$ \\
\hline $\begin{array}{l}\text { Head and neck, squamous } \\
\text { Mouth } \\
\text { Tongue } \\
\text { Pharynx } \\
\text { Larynx } \\
\text { Antrum } \\
\text { Cervical nodes }\end{array}$ & $\begin{array}{r}12 \\
3 \\
1 \\
1 \\
5 \\
1 \\
1\end{array}$ & (1) & $(10 \%)$ \\
\hline Breast & 10 & & $(8 \%)$ \\
\hline Unknown primary & 11 & (4) & $(8 \%)$ \\
\hline Skin & 3 & & $(3 \%)$ \\
\hline
\end{tabular}

\section{Discussion}

The reported incidence of hypercalcaemia varies widely (Table III). The highest incidences ranged between $3-5 \%$ and came from specialty endocrine. clinics ${ }^{3,89}$ and the National Cancer Institute, Bethesda. ${ }^{20}$ The explanation is no doubt the prevalence of endocrine and malignant diseases in these special patient populations. Our incidence of $0.6 \%$ fell within an intermediate group of $0.2-1.36 \%$ reported from hospitals with ${ }^{5-7,22}$ and without ${ }^{11}$ outpatient clinic analysis. The lowest reported incidence ${ }^{12,13}$ was $0.09 \%$ when extrapolation was made to the general population. Of great interest are the reports of Christensson who in a screen of apparently healthy adults found the extraordinarily high incidence of $1.12 \%$ when nearly half the total who had transient hypercalcaemia are included, and $0.6 \%$ when they were excluded..$^{14,15}$ This is the only study undertaken in an apparently normal population and the high incidence lacks explanation. Only two of the subjects were found to have familial hyperparathyroidism. ${ }^{16}$

Malignant disease accounted for $45 \%$ of our causes of sustained hypercalcaemia and was also the most common cause in most analyses, the average frequency being $38.5 \%$ (Table IV). This contrasted to Christensson's figure of $2 \%$ of apparently normal adults who harboured malignant disease when found to be hypercalcaemic during a health screening programme. ${ }^{14,15}$ Our major primary sites of malignancy were the lung, gastrointestinal and urogenital tracts, haematological, head and neck and breast which was essentially similar to those reported by others.

Primary hyperparathyroidism accounted for $16.5 \%$ of our cases. The average proportion was $25 \%$ in hospital series and $71 \%$ in the health screen reported by Christensson. . $^{14,15}$ It was noteworthy that the discovery of over half our cases of primary hyperparathyroidism was directly attributable to the survey; not

Table III Incidence of hypercalcaemia

\begin{tabular}{|c|c|c|c|c|}
\hline Population studied & Incidence & Time & $\begin{array}{c}\text { Upper } \\
\text { limit } \\
(\text { mmol/l) }\end{array}$ & Reference \\
\hline Endocrine, renal stone clinic & $3.65 \%(292 / 8000)$ & $1954-1961(7 \mathrm{y})$ & 2.8 & 3 \\
\hline Hospital, outpatients & $0.24 \%(61 / 25847)$ & $1959-1965(5 y)$ & 2.6 & $4,5,6$ \\
\hline Hospital, outpatients & $0.21 \%(126 / 60,000)$ & $1965-1966(1 \mathrm{y})$ & 2.6 & 7 \\
\hline Hospital, outpatients, endocrine clinic & $3.59 \%(72 / 2005)$ & $? 1966(1 \mathrm{y})$ & 2.8 & 9 \\
\hline Hospital & $0.42 \%(34 / 8027)$ & $1969-1970$ (8 months) & 2.6 & 11 \\
\hline Hospital, outpatients & $\begin{array}{c}0.09 \% \\
\text { ( } 90 / 100,000 \\
\text { population) }\end{array}$ & 1970-1971 (9 months) & 2.8 & 12 \\
\hline 20-63 years health screen & $1.12 \%(178 / 15903)$ & $1971-1973(2 y)$ & 2.8 & 14,15 \\
\hline Hospital (cancer referral) & $5 \% \quad(890 / 17,706)$ & $1970-1977(6 y)$ & 2.8 & 20 \\
\hline Hospital, outpatients & $1.36 \%(334 / 24,500)$ & $1978-1979(1 \mathrm{y})$ & 2.6 & 22 \\
\hline Hospital & $0.6 \% \quad(338 / 58,053)$ & $1983-1984(1 \mathrm{y})$ & 2.6 & This study \\
\hline
\end{tabular}




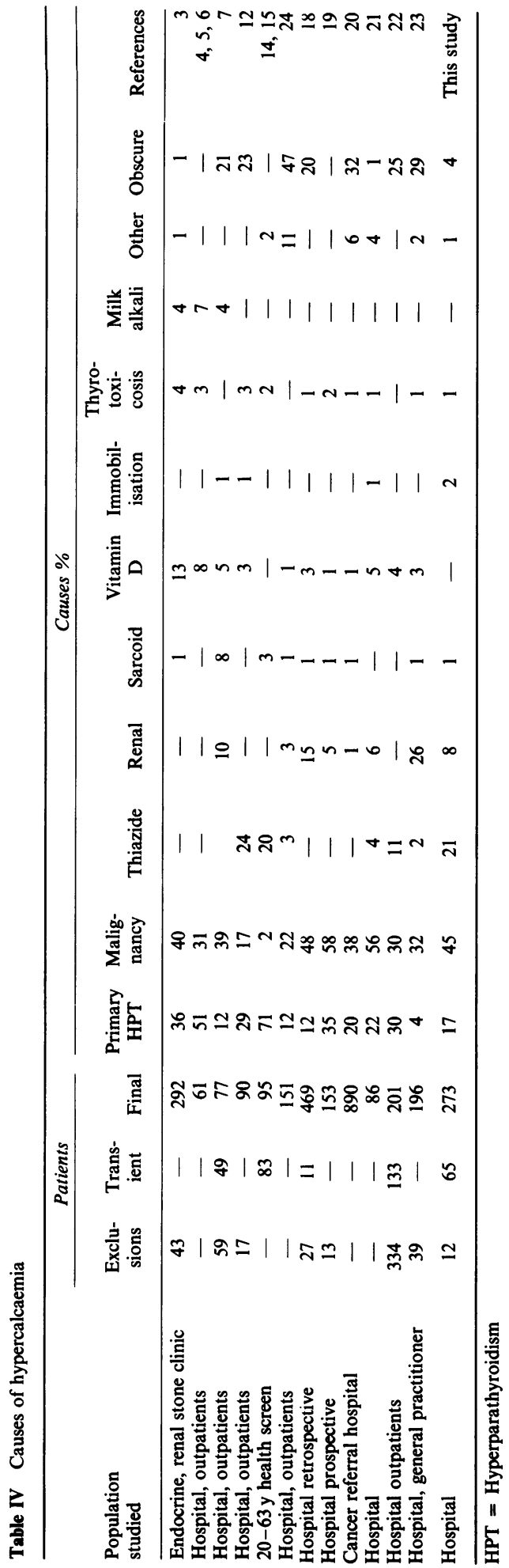

only this, but many of these cases had symptoms or complications directly attributable to the disease and the attending clinician was unaware of their implication. Only $25 \%$ of our patients were completely asymptomatic. We would have expected the proportion of asymptomatic patients to have increased progressively over the two decades of the reports we reviewed but this was not the case. It appears that clinicians do not readily note hypercalcaemia in routine autoanalyser reports, nor does the possibility of primary hyperparathyroidism readily come to mind when one of the many manifestations are present.

We attributed hypercalcaemia to thiazide administration in $21 \%$ of cases, doing this with great caution as patients with other causes of hypercalcaemia could have been receiving thiazides, and, indeed, thiazides have been reported to provoke hypercalcaemia in patients with primary hyperparathyroidism. ${ }^{25} \mathrm{We}$ did not encounter hypervitaminosis D or the milk alkali syndrome and the decreasing incidence of the last two causes must be due to an alteration in prescribing patterns over the years surveyed.

Our incidence of primary hyperparathyroidism was $16.5 \%$ of hypercalcaemiac patients. The reported incidence amongst hypercalcaemics varies widely (Table V): the highest incidences were $71.5 \%$ of an apparently normal population ${ }^{14,15}$ and $35.5 \%$ in a series before automated analyses when estimations were probably mainly problem orientated. ${ }^{3}$ We cals culated an average of $22.5 \%$ of hypercalcaemie patients in hospital had primary hyperparathyroidisn when we combined our proportion with other hospital series.

When we calculated our incidence as a proportion of hospital patients we found this to be $0.78 \%$ or $78 /$ 100,000 . Once again we found a wide variation in estimates but calculated an average hospital incidence with a renal stone clinic excluded ${ }^{3}$ of $0.19 \%$ or $190 /$ 100,000 . Christensen's is the only study of which we are aware in apparently normal adults and his incidence was $0.52 \%$ or $52 / 100,000 .^{14,15}$

Our major concern was that occult primary hyperparathyroidism could be overlooked and true incidences underestimated if a significant proportion of cases were dismissed as transient, obscure or uninvestigated. We decided that our 12 uninvestigated cases should be excluded; others investigating the incidence and causes of hypercalcaemia have also recorded exclusions and in some instances these were significant in number (Table IV).

As many as $19 \%$ of our patients had transient hypercalcaemia and in most instances we were able to find a cause such as therapy during an acute cardiac event, parenteral nutrition or calcium infusion. In 19 instances, however, we had no explanation for the phenomenon. In none of the unexplained group did the calcium exceed $3.0 \mathrm{mmol} / \mathrm{l}$, and all had only a 
Table $\mathbf{V}$ Incidence of hyperparathyroidism

\begin{tabular}{|c|c|c|c|c|c|c|}
\hline \multicolumn{3}{|c|}{ Incidence } & \multicolumn{4}{|c|}{ Patients } \\
\hline $\begin{array}{l}\text { Percentage of } \\
\text { hypercal- } \\
\text { caemics }\end{array}$ & $\begin{array}{r}\text { Perc } \\
\text { popula }\end{array}$ & $\begin{array}{l}\text { ge of } \\
\text { sampled } \\
\qquad(\text { Total })\end{array}$ & Total & $\begin{array}{c}\text { Operation } \\
\text { proven }\end{array}$ & Asymptomatic \% & Reference \\
\hline 35.6 & 1.3 & $(+8000) \dagger$ & 104 & 104 & 10,6 & 3 \\
\hline 51 & 0.12 & $(25847)^{*}$ & 31 & 26 & 74,2 & 5 \\
\hline - & 0.1 & $(50330)^{*}$ & 50 & 44 & 80 & 6 \\
\hline 11.6 & 0.015 & $( \pm 60000)^{*}$ & 9 & 8 & $?$ & 7 \\
\hline 9.7 & 0.35 & $(2005) \dagger$ & 7 & 6 & 0 & 8,9 \\
\hline- & 0.054 & $(87500)^{*}$ & 47 & 47 & 25,5 & 10 \\
\hline 17.6 & 0.075 & $(8027)^{*}$ & 6 & 6 & 16,6 & 11 \\
\hline 28.9 & 0.028 & $\ddagger$ & 26 & 9 & $?$ & 12,13 \\
\hline 71.5 & 0.52 & $(15903) \S$ & 82 & 58 & 71 & 14,15 \\
\hline- & 0.28 & - & 28 & - & - & 17 \\
\hline 11.9 & - & - & 59 & 30 & - & 18 \\
\hline 34.6 & - & - & 51 & 20 & - & 19 \\
\hline 19.6 & 0.98 & $(17706)^{*}$ & 174 & - & - & 20 \\
\hline 21.1 & - & $*$ & 19 & 7 & 42 & 21 \\
\hline 17.9 & 0.15 & $(24500)^{*}$ & 36 & - & 25 & 22 \\
\hline 2.6 & - & - & 7 & - & - & 23 \\
\hline 16.5 & 0.078 & $(58053)^{*}$ & 45 & 25 & 25 & This study \\
\hline
\end{tabular}

*Hospital, outpatients; † endocrine, renal stone clinic; $\ddagger$ extrapolation to population; §healthy adults

single elevation. It is tempting to invoke cuff occlusion as an explanation but this is unlikely. ' While this could have been due to laboratory error we are more comfortable in categorizing this group as obscure transient hypercalcaemia. Other authors have either recorded or not reported this problem (Table IV).

In conclusion we found an incidence of hypercalcaemia of $0.6 \%$ of 58,053 hospital in-patients which fell within the range of $0.2-1.36 \%$ of the reports we surveyed. Where malignancy and endocrine disorders predominate an incidence of $3-5 \%$ could be expected and confirmation of the incidence in the apparently normal population is required. Malignancy accounted

\section{References}

1. Dent, D.M. Jaros, C.G., Belonje, P. \& van Hoorn-Hickman, R. Does cuff occlusion affect serum calcium ( and is it clinically important)? $S$ Afr J Surg 1983, 21: 164.

2. Lo Cascio, V., Vallaperta, P., Adami, S. et al. Discriminant analysis in the differential diagnosis of hypercalcaemia. Clin Endocrinol 1978, 8: 349-356.

3. Gordan, G.S., Eisenberg, E., Loken, H.F., Gardner, B. \& Hayashida, T. Clinical endocrinology of parathyroid hormone excess. In Pincus, G. (ed) Recent Progress in Hormone Research, Vol 18. Academic Press, New York, 1962, p. 297.

4. Boonstra, C.E. \& Jackson, C.E. The clinical value of routine serum calcium analysis. Ann Intern Med 1962, 57: 963-969. for $45 \%$ of our causes of sustained hypercalcaemia, the average reported frequency being $38.5 \%$. Our incidence of primary hyperparathyroidism was $16.5 \%$ (or 78/100,000) and the discovery of many cases was directly attributable to the survey; the average of previous reports was $22.5 \%$ (or $190 / 100,000$ ).

\section{Acknowledgements}

The South African Medical Research Council is thanked for financial support. The hard work of Gail Brinkworth, SRN, is gratefully acknowledged.
5. Boonstra, C.E. \& Jackson, C.E. Hyperparathyroidism detected by routine calcium analysis. Prevalence in a clinic population. Ann Intern Med 1965, 63: 468-474.

6. Boonstra, C.E. \& Jackson, C.E. Serum calcium survey for hyperparathyroidism. Am J Clin Path 1971, 55: 523526.

7. McLellan, G., Baird, C.W. \& Melick, R. Hypercalcaemia in an Australian hospital adult population. Med $J$ Aust 1986, ii: 354-356.

8. Keating, F.R. Diagnosis of primary hyperparathyroidism. JAMA 1961, 178: 547-555.

9. Keating, F.R., Jones, J.D., Elveback, L.R. Distribution of serum calcium and phosphorus values in unselected ambulatory patients. J Lab Clin Med 1969, 74: 507-514. 
10. Haff, R.C., Black, W.C. \& Ballinger, W.F. Primary hyperparathyroidism: changing clinical, surgical and pathological aspects. Ann Surg 1970, 171: 85-92.

11. Mays, E.T. \& Weakley, S.D. Serum multichannel autoanalysers in the detection of hypercalcaemia and hyperparathyroidism. Surg Gynecol Obstet 1971, 133: 603-608.

12. Heedman, P. Stenstrom, G. Clinical findings in patients with hypercalcaemia. Acta Med Scand 1973, 193: 167173.

13. Stenstrom, G. \& Heedman, $P$. Clinical findings in patients with hypercalcaemia. Acta Med Scand 1974, 195: $473-477$.

14. Christensson, T., Hellstrom, K., Wengle, B., Alveryd, A. \& Wikland, B. Prevalence of hypercalcaemia in a health screening in Stockholm. Acta Med Scand 1976, 200: 131137.

15. Christensson, T., Hellstrom, K. \& Wengle, B. Clinical and laboratory findings in patients with hypercalcaemia. Acta Med Scand 1976, 200: 355-360.

16. Christensson, T., Familial hyperparathyroidism. Ann Intern Med 1976, 85: 614-615.

17. Heath, H., Hodgson, S.F. \& Kennedy, M.A. Primary hyperparathyroidism. Incidence, morbidity and potential economic impact in a community. $N$ Engl $J$ Med 1980, 302: 189-193.
18. Fisken, R.A., Heath, D.A. \& Bold, A.M. Hypercalcaemia - a hospital survey. $Q J$ Med 1980, 196: 405-418.

19. Fisken, R.A., Heath, D.A., Somers, S. \& Bold, A.M. Hypercalcaemia in hospital patients. Lancet 1981, i: 202-207.

20. Burt, M.E. \& Brennan, M.F. Incidence of hypercalcaemia and malignant neoplasm. Arch Surg 1980, 115: 704-707.

21. Burkhart, E. \& Kistler, H.J. Hypercalciamie bei hospitalisierten patienten. Schweiz Med Wochenschr 1981, 111: 2017-2023.

22. Harrop, J.S., Bailey, J.E. \& Woodhead, J.S. Incidence of hypercalcaemia and primary hyperparathyroidism in relation to the biochemical profile. J Clin Path 1982, 35: $395-400$.

23. Rajathurai, A. \& Cove-Smith, R. Hypercalcaemia in Cleveland; a hospital-based survey. J Roy Soc Med 1984, 77: 742-746.

24. Zawada, E.T., Lee, D.B.N. \& Kleeman, C.R. Causes of hypercalcaemia. Postgrad Med 1979, 66: 91-100.

25. Parfitt, A.M. Chlorothiazide-induced hypercalcaemia in juvenile osteoporosis and hyperparathyroidism. $N$ Engl $J$ Med 1969, 281: 55-59. 